\title{
ĐỀ XUÂT PHÂN VÙNG CHỬC NĂNG VÙNG BỜ THÀNH PHỐ HỒ CHÍ MINH
}

\author{
Ngô Nam Thịnh ${ }^{1}$, Nguyễn Huy Anh', Nguyễn Kỳ Phùng²
}

Tóm tắt: Phân vùng chức năng vùng bò̀ Hồ Chí Minh được xây dựng trên co sở tích hợp các yếu tố tư nhiên, môi trường và kinh tế - xã họi dưới sụ trợ giúp của phần mềm GIS. Kết quả nghiên cúu đã phân chia lãnh thổ vùng bò̀ thành phố Hồ Chí Minh thành 4 vùng, 23 tiểu vùng và 04 chức năng chính: chức năng bảo vệ, bảo tồn với diện tích 22.370,97 ha chiếm 35\% diện tích; chức năng phục hồi hệ sinh thái 4.017,12 chiếm 6\%; chức năng không gian sinh sống 1.854,32 ha chiếm 3\%; chức năng phát triển kinh tế - xã hội có diện tích 35.452,68 ha chiếm 56\% diện tích quy hoạch. Kết quả phân vùng chức năng vùng bò̀ Hồ Chi Minh là cơ sở khoa hoc quan trọng để Hồ Chí Minh xây dụng nhũng giải pháp phù hợp để phát triển kinh tế - xã hội và bảo vệ môi truờng trong tuơng lai.

Từ khóa: Vùng bò̀, huyện Cần Giơ, chức năng vùng bò̀.

Ban Biên tập nhận bài: 05/10/2019 Ngày phản biện xong: 22/11/2019 Ngày đăng bài: 25/01/2020

\section{1. Đặt vấn đề}

Phân vùng và quy hoạch là quá trình nghiên cứu phân chia lãnh thổ ra thành một hệ thống các vùng, là quá trình vạch ra hoặc tiếp tục điều chỉnh ranh giới hợp lý của toàn bộ hệ thống vùng; định hướng chuyên môn hoá sản xuất cho vùng và xác định cơ cấu kinh tế vùng ứng với các kế hoạch phát triển dài hạn. Phân vùng và quy hoạch phục vụ đắc lực cho công tác kế hoạch hóa dài hạn, tạo điều kiện thuận lợi cho phân bố lực lượng sản xuất và phân công lao động hợp lý trên phạm vi vùng được phân, làm cơ sở cho việc chỉnh sửa ranh giới các đơn vị hành chính phù hợp với nguyên tắc thống nhất quản lý kinh tế với quản lý hành chính.

Đối với các vùng ven biển, phân vùng khai thác và sử dụng tài nguyên vùng bờ biển là một trong những công cụ quan trọng để xây dựng quy hoạch sử dụng tài nguyên và bảo vệ môi trường biển, thực hiện quản lý tổng hợp vùng bờ phục vụ các mục đích: Phát triển kinh tế biển, bảo vệ môi trường, các hệ sinh thái và phát triển các khu bảo tồn thiên nhiên, bảo vệ các vùng bờ biển dễ bị tổn thương, bảo vệ các công trình nổi, ngầm trên biển.
Thành phố Hồ Chí Minh (TP.HCM) là một đầu mối giao thông quan trọng về cả đường bộ, đường thủy và đường không, nối liền các tỉnh trong vùng và còn là một cửa ngõ quốc tế. Huyện Cần Giờ là huyện duy nhất của Thành phố Hồ Chí Minh giáp biển, nằm ở phía Đông $\mathrm{Nam}$, cách trung tâm thành phố khoảng $50 \mathrm{~km}$ đường bộ. Cần Giờ giống như một hòn đảo tách biệt với xung quanh, bốn bề là sông và biển.

Tài nguyên vùng ven biển TP.HCM đa dạng và phong phú, vừa là điều kiện thuận lợi để phát triển kinh tế biển (ngành du lịch, thủy sản, hàng hải...), vừa là nguy cơ nảy sinh mâu thuẫn, xung đột trong khai thác, sử dụng chung các nguồn tài nguyên - đòi hỏi cơ chế quản lý hợp lý, đa ngành, đảm bảo cân bằng giữa phát triển kinh tế và bảo vệ môi trường. Chính vì vậy việc nghiên cứu phân vùng chức năng vùng bờ phục vụ cho mục tiêu phát triển kinh tế bền vững là nhiệm vụ hết sức cần thiết.

\section{Lãnh thổ và phương pháp nghiên cứu}

\subsection{Khái quát vùng bờ thành phố Hồ Chí}

\section{Minh}

Cần Giờ nằm ở vị trí từ $106^{\circ} 46^{\prime} 12^{\prime \prime}$ đến $107^{\circ} 00^{\prime} 50^{\prime \prime}$ kinh độ Đông và từ $10^{\circ} 22^{\prime} 14^{\prime \prime}$ đến

${ }^{1}$ Đại học Tài nguyên và Môi trường thành phố Hồ Chí Minh

${ }^{2}$ Sở Khoa học và Công nghệ thành phố Hồ Chí Minh

Email:nnthinh@hcmunre.edu.vn 
1040’00” vĩ độ Bắc. Cần Giờ là một trong 5 huyện ngoại thành của TP.HCM, nằm về hướng Đông Nam, cách trung tâm thành phố khoảng 50 $\mathrm{km}$ đường bộ, có hơn $20 \mathrm{~km}$ bờ biển chạy dài theo hướng Tây Nam - Đông Bắc, có các cửa sông lớn của các con sông Lòng Tàu, Cái Mép, Gò Gia, Thị Vải, Soài Rạp, Đồng Tranh [5]. Chiều dài từ Đông sang Tây là $30 \mathrm{~km}$, từ Bắc xuống Nam là $35 \mathrm{~km}$. Cần Giờ là huyện duy nhất của Tp. HCM giáp biển, nằm ở phía Đông Nam, Cần Giờ giống như một hòn đảo tách biệt với xung quanh, bốn bề là sông và biển. Vùng bờ Cần Giờ bao gồm 4 xã ven biển là Thạnh An, TT
Cần Thạnh, Long Hòa, Lý Nhơn và phần biển ven bờ ra đến 6 hải lý.

Tổng diện tích tự nhiên vùng bờ huyện Cần Giờ là 63.695,09 ha bao gồm diện tích tự nhiên thị trấn Cần Thạnh và 3 xã Long Hòa, Thạnh An, Lý Nhơn và diện tích biển ven bờ 6 hải lý. Đặc điểm nổi bật về thổ nhưỡng của vùng nghiên cứu là phèn và mặn $[4,6]$. Vùng ngập mặn ở huyện Cần Giờ chiếm tới 56,7\% diện tích toàn huyện, tạo nên hệ sinh thái rừng ngập mặn độc đáo, trong đó chủ yếu là cây đước, cây bần, mắm $[1,3]$.

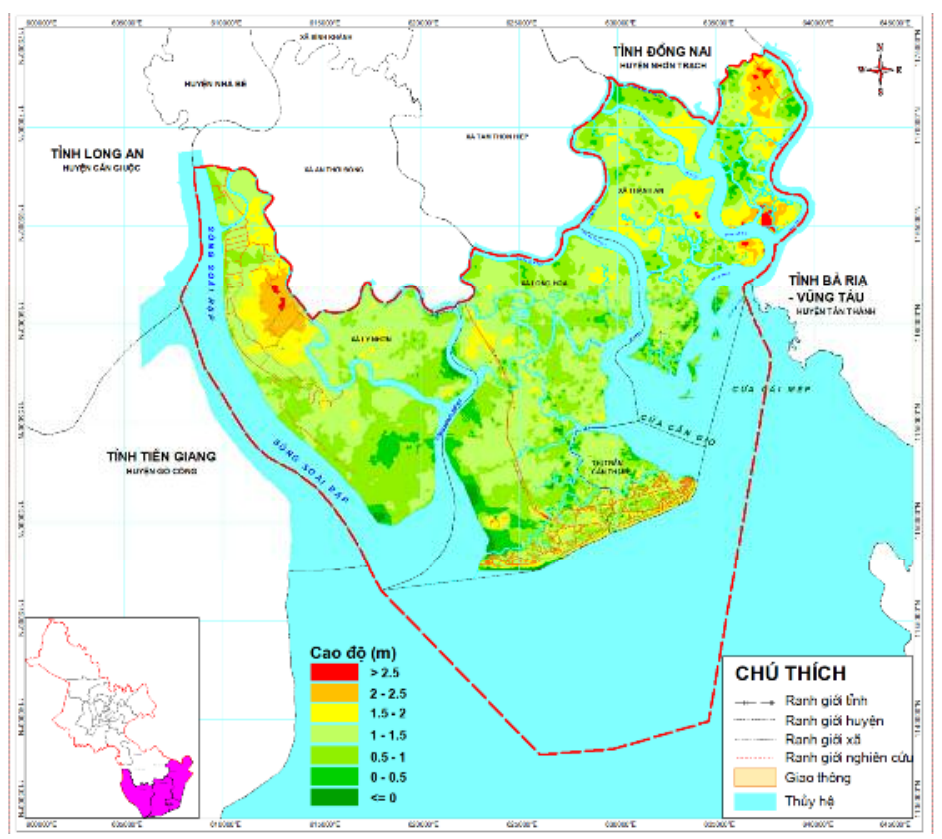

Hình 1. Khu vục nghiên cưu

\subsection{Phương pháp nghiên cứu}

2.2.1. Nguyên tắc phân vùng chức năng vùng bò Tp. Hồ Chí Minh

Nghiên cứu xây dựng phân vùng chức năng vùng bờ Hồ Chí minh được thực hiện theo các nguyên tắc sau:

Nguyên tắc khách quan: Xuất phát từ quan niệm rằng, vùng là một thực thể khách quan, nó được hình thành do tác động tương hỗ lâu dài của các yếu tố tự nhiên, tuân theo quy luật tự nhiên về dòng năng lượng và trao đổi vật chất, vì vậy cần vận dụng những đặc tính khách quan đó của vùng ở trạng thái cân bằng nội tại trong các chính sách nói chung và trong điều tiết sự mất cân đối của vùng do tác động của con người nói riêng [2].

Nguyên tắc đồng nhất tương đối của vùng: Phân vùng chức năng vùng bờ (PVCNVB) dựa trên sự phân tích, đánh giá tổng điều kiện tự nhiên, KT-XH và môi trường. Mỗi vùng được phân định theo sự đồng nhất về tất cả các tiêu chí phân vùng, tuy nhiên không thể có sự đồng nhất tuyệt đối, mà đó chỉ là sự đồng nhất tương đối.

Phù hợp với chức năng môi trường sinh thái: Chức năng của vùng thể hiện sự gắn kết chặt chẽ theo chiều ngang giữa các hợp phần trong mỗi vùng, từ trung tâm đến ngoại vi. Mỗi hệ sinh thái đều có một vài chức năng chính riêng và một số 


\section{BÀI BÁO KHOA HỌC}

chức năng khác.

Phù hợp với yêu cầu quản lý: PVCNVB của một địa phương phục vụ cho nhiệm vụ cho mục tiêu khai thác và sử dụng hợp lý lãnh thổ chính là xây dựng cơ sở khoa học để điều hoà sự phát triển trong khả năng chịu tải của các hệ sinh thái và môi trường tự nhiên. phải dựa trên các cơ sở khoa học sao cho, một mặt phản ảnh được thực tế khách quan và đặc thù của lãnh thổ, mặt khác, vừa mang tính lý thuyết, hệ thống, nhằm rút được kinh nghiệm về phương pháp luận và phương pháp kỹ thuật có thể áp dụng cho các lãnh thổ khác.

\subsubsection{Phuoong pháp nghiên cứu}

Tính khoa học trong phân vùng: PVCNVB

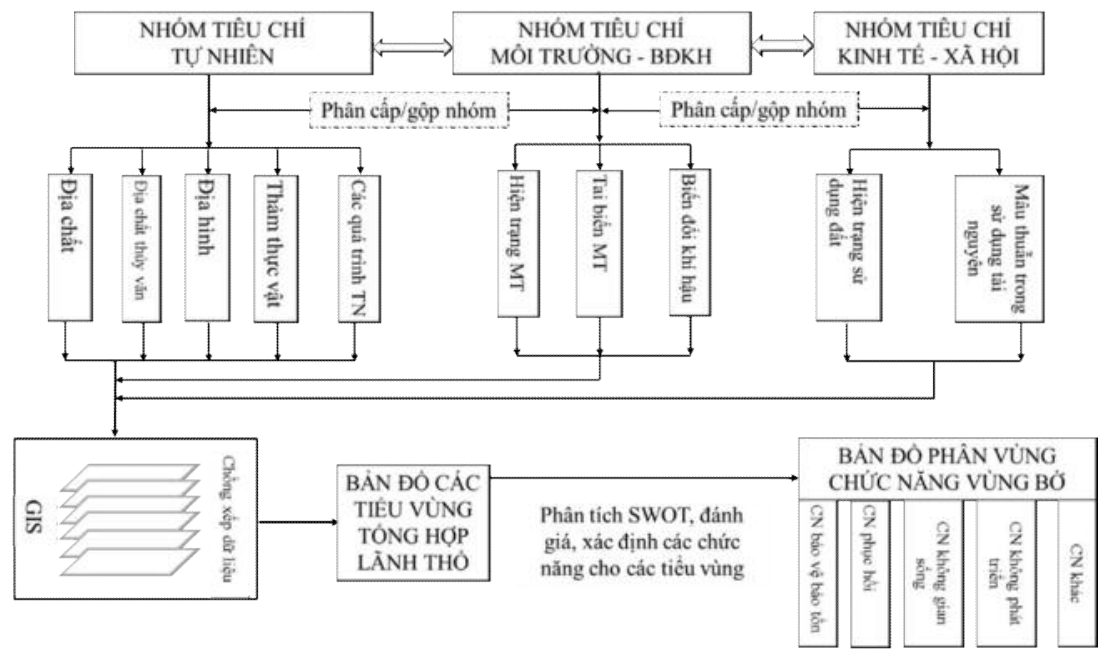

Hình 2. So đồ khung logic xây dựng bản đồ phân vùng CNVB Hồ Chí Minh

Ngoài các phương pháp truyền thống (thu thập, tổng hợp và phân tích tài liệu), phương pháp GIS và phân tích SWOT chính là hai phương pháp chủ đạo trong bài báo này (hình 2).

Phân tích hiện trạng môi trường, điều kiện địa lý (tự nhiên, xã hội) là cơ sở quan trọng và thể hiện mối liên hệ mật thiết với phân vùng chức năng vùng bờ. Ngoài ra các tiêu chí về môi trường và tai biến, mâu thuẫn trong sử dụng tài nguyên ở vùng bờ cũng được sử dụng trong quá trình xây dựng bản đồ phân vùng chức năng vùng bờ Hồ Chí Minh.

Ngoài điều kiện tự nhiên, KT-XH và môi trường thì trong nghiên cứu $\mathrm{PVCNVB}$ cần phân tích các tai biến thiên nhiên và lồng ghép các yếu tố biến đổi khí hậu trong giai đoạn phân vùng môi trường và đề xuất các không gian bảo vệ môi trường.

\section{Bảng 1. Tiêu chí phân vùng chức năng vùng bò̀}

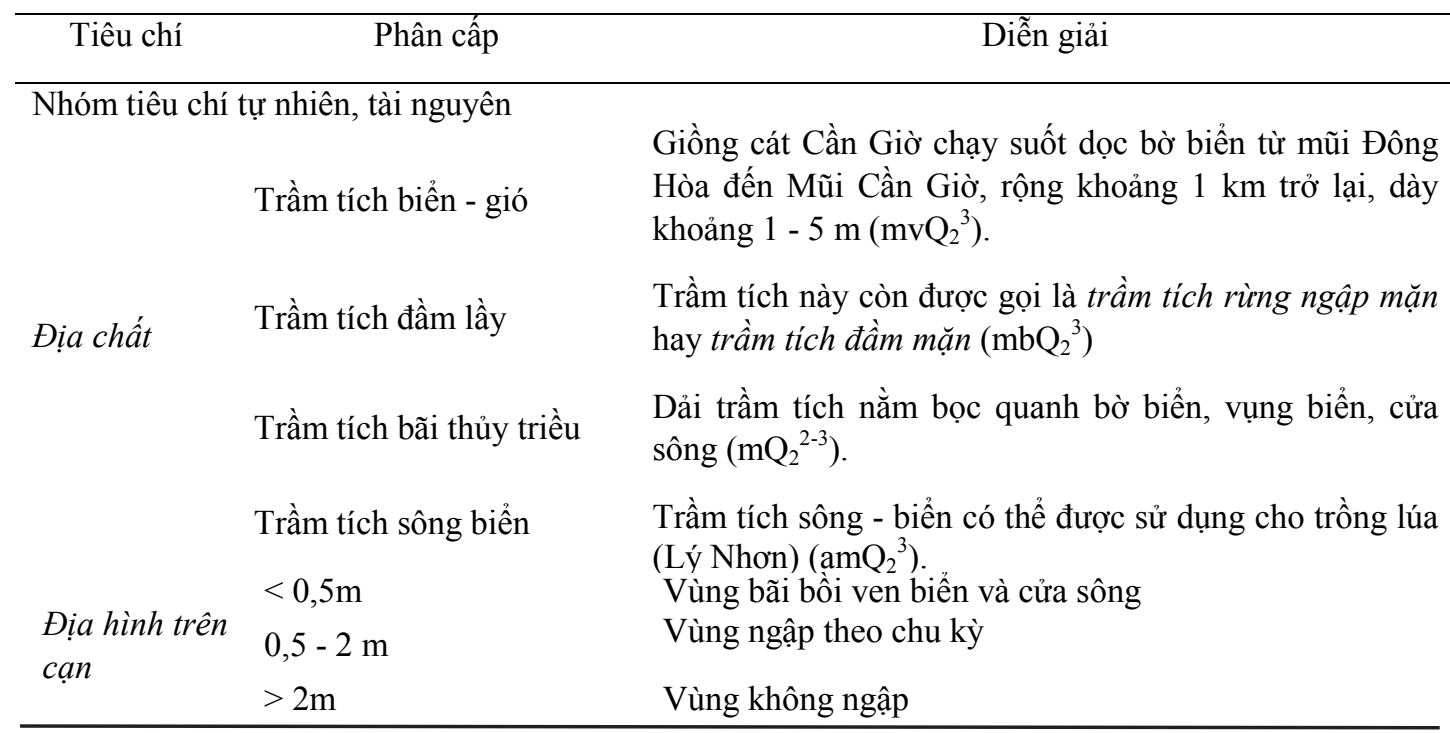




\begin{tabular}{|c|c|}
\hline \multirow{2}{*}{$\begin{array}{l}\text { Địa hình } \\
\text { biền ven bò̀ }\end{array}$} & $<-6 m$ \\
\hline & $>-6 m$ \\
\hline \multirow{3}{*}{$\begin{array}{l}\text { Thảm thục } \\
\text { vật }\end{array}$} & $\begin{array}{l}\text { Rừng ngập mặn } \\
\text { Lúa - hoa màu }\end{array}$ \\
\hline & Cây lâu năm \\
\hline & $\begin{array}{l}\text { Khu vực có độ che phủ } \\
\text { thấp }\end{array}$ \\
\hline \multirow{4}{*}{ Thổ nhữ̃ng } & Đất mặn \\
\hline & Đất phèn \\
\hline & Đất phù sa \\
\hline & Đất cát \\
\hline \multirow{4}{*}{$\begin{array}{l}\text { Đa dạng sinh } \\
\text { học }\end{array}$} & $\begin{array}{l}\text { Vùng bảo vệ nghiêm ngặt } \\
\text { (DTSQ) }\end{array}$ \\
\hline & Vùng đệm (DTSQ) \\
\hline & Vùng chuyển tiếp \\
\hline & Vùng biển ven bờ \\
\hline
\end{tabular}

Công ước RAMSAR về phân chia vùng sinh thái biển và ven biển; ngoài ra độ sâu $(-6 \mathrm{~m})$ phù hợp với vùng bãi triều ven biển.

Gộp nhóm theo đặc điểm của thảm thực vật; Cần Giờ có diện tích làm muối lớn, đang được phát triển mạnh ở thời điểm hiện tại và trong quy hoạch chính vì vậy tách riêng diện tích làm muối thành 1 loại.

Phân bố ở khu vực tây bắc Cần giờ

Phân bố khu vực lòng chảo Cần Giờ

Xã Lý Nhơn

Phân bố dọc theo bờ biển

Phân vùng khu dự trữ sinh quyển Cần Giờ và vùng biển ven bờ đến 6 hải lý. Trên cơ sở đánh giá đa dạng sinh học các nghiên cứu trước đây đã phân chia Khu dự trữ sinh quyển Cần Giờ thành 3 vùng: Bảo vệ nghiêm ngặt, vùng đệm và vùng chuyển tiếp.

Nhóm tiêu chí về môi trường - tai biến tự nhiên

\begin{tabular}{ll}
$\begin{array}{l}\text { Nhây cảm } \\
\text { môi truoòng } \\
\text { vùng bò̀ }\end{array}$ & $\begin{array}{l}\text { Nhạy cảm cao cảm trung bình } \\
\text { Nhạy cảm thấp }\end{array}$ \\
$\begin{array}{l}\text { Xói lở - bồi } \\
\text { tụ bờ biển }\end{array}$ & Khu vực xói lở \\
$\begin{array}{l}\text { Nuóc biển } \\
\text { dâng và ngập } \\
\text { lụt }\end{array}$ & Khu vực bồi tụ̂ ngập \\
\hline
\end{tabular}

Nhóm tiêu chí về kinh tế - xã hội

Hiện trạng khai thác sư dụng tài nguyên

Mâu thuẫn sủ dụng tài nguyên
Sản xuất nông nghiệp

Nuôi trồng thủy sản Làm muối

Du lịch - dịch vụ

Đô thị

Phát triển giao thông, cảng, đô thị với bảo tồn

Phát triển nông nghiệp với bảo tồn

Phát triển du lịch với môi trường
Được tổng hợp từ các bản đồ nhạy cảm thành phần nhu: nhạy cảm đường bờ, nhạy cảm sinh vật và nhạy cảm nhân sinh.

Khu vực đường bờ thường xuyên xói lở

Khu vực đường bờ bồi tụ

Kịch bản biến đổi khí hậu ở khu vực Cần Giờ, chế độ thủy triều.

Khai thác tài nguyên đất phục vụ phát triển nông nghiệp, chăn nuôi

Khai thác đất, mặt nước phát triển NTTS

Phát triên nghê làm muôi

Khai thác các tài nguyên phục vụ phát triển du lịch như: di tích, khảo cổ, bãi biển, khu bảo tồn, đảo...

Sử dụng đất cho phát triển đô thị

Phá rừng phát triển mạng lưới giao thông; phát triển đô thị

Phá rừng làm ao NTTS, làm muối

Hoạt động du lịch ảnh hưởng đến môi trường, đa dạng sinh học 


\section{Kết quả nghiên cứu}

\subsection{Hệ thống phân vùng ở vùng bò̀}

Từ phân tích sự phân hóa lãnh thổ vùng bờ Hồ Chí Minh theo các yếu tố tự nhiên và nhân sinh nhận thấy rằng, địa bàn bị chia cắt mạnh bởi hệ thống sông, kênh dày đặc. Xét trên kết quả phân hóa qua sự chồng xếp các dữ liệu thành phần đề tài đã xác 2 cấp phân vị: cấp vùng (cấp I), cấp tiểu vùng (cấp II). Ở mỗi cấp yếu tố trội đặc trưng được lựa chọn để làm cơ sở cho việc phân vùng. Cấp tiểu vùng là đơn vị cơ sở có tính đồng nhất cao, với đặc trưng về sử dụng tài nguyên, chức năng môi trường sinh thái và định hướng sử dụng riêng (Hình 3).

\subsection{Phân vị cấp vùng lãnh thổ}

Mặc dù lãnh thổ vùng bờ Tp. Hồ Chí Minh được phân hóa khá đa dạng, nhưng xét về tổng thể về vị trí địa lý, địa hình, thảm thực vật, tác động nhân sinh, sự chi phối của hệ thống thủy văn, đặc biệt là sự chi phối của đặc điểm địa chất và đa dạng sinh học. Căn cứ vào sự phân hóa lãnh thổ và nguyên tắc phân vùng được trình bày ở trên, với cách tiếp cận theo hướng tổng hợp đã chia lãnh thổ nghiên cứu thành thành 4 vùng là: Vùng rừng ngập mặn $(\mathrm{I})$; Vùng đất cát ven biển (II): Vùng đất cát ven sông Soài Rạp (III); Vùng ngập nước (IV) (Hình 4).

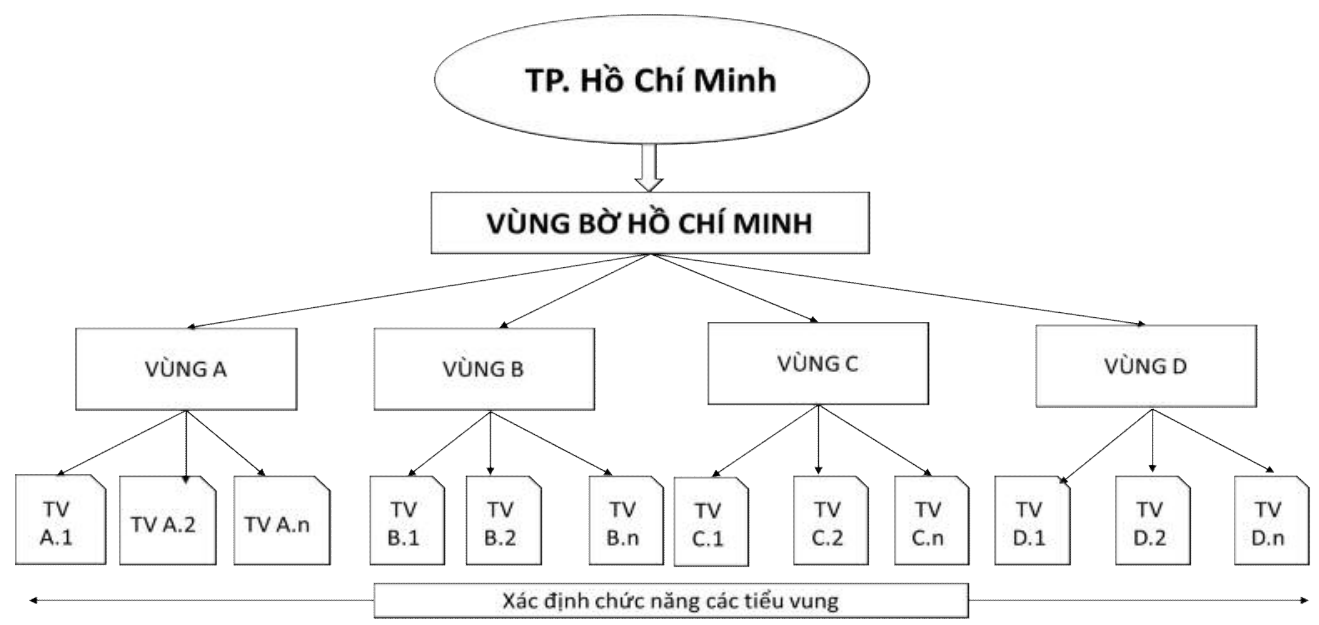

Hình 3. Sở đồ cấp phân vị bản đồ phân vùng chức năng vùng bờ Hồ Chi Minh

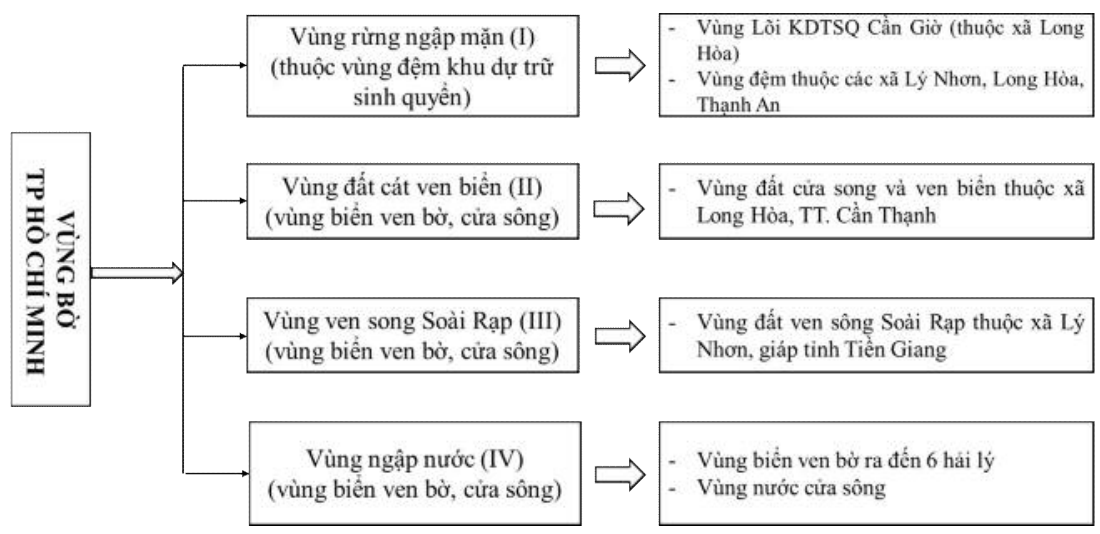

Hình 4. So đồ phân chia cấp vùng trong PVCN vùng bò̀ Tp Hồ Chí Minh

\subsection{Phân vị cấp tiểu vùng lãnh thổ}

Lãnh thổ vùng bờ Tp. Hồ Chí Minh do các yếu tố kiến tạo địa chất, thủy văn chi phối chính. Vì vậy để phân chia ra cấp tiểu vùng thì các tiêu chí như điều kiện thổ nhưỡng, hiện trạng khai thác và sử dụng tài nguyên được xem là yếu tố được ưu tiên. Theo đó từ mỗi vùng căn cứ thêm đặc điểm khai thác tài nguyên để tiếp tục chia ra các đơn vị lãnh thổ quy mô nhỏ, đó là các tiểu vùng. Đây là phân vị nhỏ nhất trong hệ thống 
phân vị ở địa bàn nghiên cứu, được gọi là tiểu vùng lãnh thổ. Mặc dù địa bàn nghiên cứu bị phân hóa rất mạnh, nên có thể phân ra các phân vị nhỏ hơn nữa tùy thuộc vào mục đích sử dụng. Tuy nhiên, để phục vụ công tác phân vùng chức năng ở vùng bờ, thì đơn vị tiểu vùng được lựa chọn là đơn vị cơ sở (Hình 5).

\subsection{Phân hóa lãnh thổ vùng bò̀ Hồ Chí Minh}

Từ kết quả phân tích tổng hợp các yếu tố thành phần đã phân chia lãnh thổ nghiên cứu 4 vùng chức năng: (I) Vùng rừng ngập mặn; (II) Vùng đất cát ven biển; (III) Vùng đất cát ven sông Soài Rạp; (IV) Vùng ngập nước và 23 tiểu vùng. Trên cơ sở phân tích điều kiện KT-XH, trong mối quan hệ với điều kiện tự nhiên, tài nguyên và những vấn đề môi trường. Đó là đơn vị cơ sở để xác định chức năng đặc trưng cho từng tiểu vùng (Bảng 2).

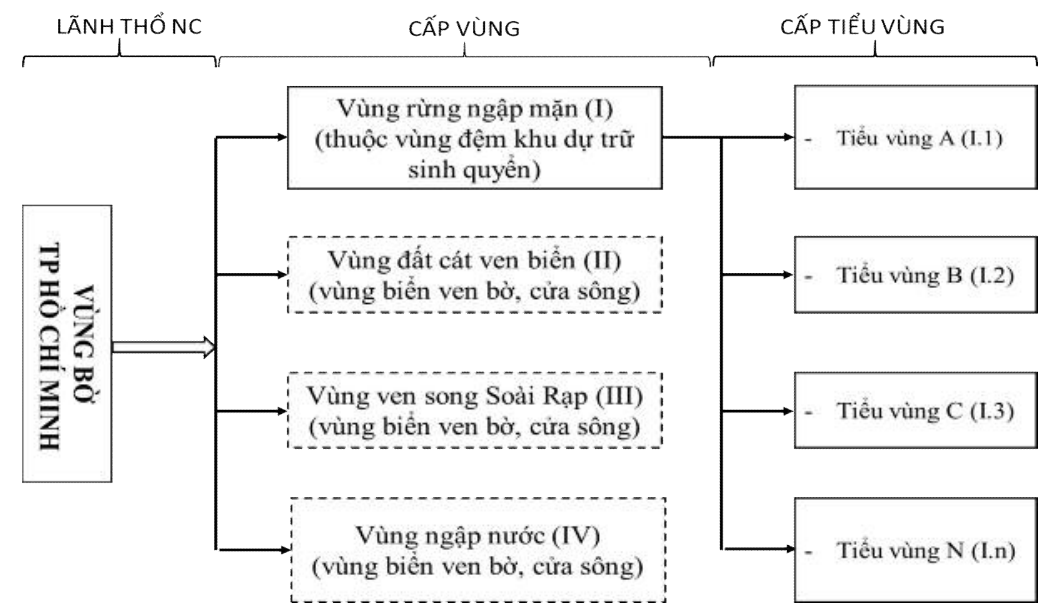

Hình 5. So đồ phân cấp tiểu vùng

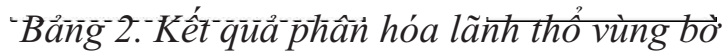

\begin{tabular}{|c|c|c|c|c|}
\hline \multicolumn{2}{|c|}{ Vùng } & \multicolumn{2}{|l|}{ Tiểu vùng } & \multirow{2}{*}{$\begin{array}{c}\text { Diện tích } \\
\text { (ha) }\end{array}$} \\
\hline Tên gọi & Ký hiệu & Tên gọi & Ký hiệu & \\
\hline & \multirow{4}{*}{ I } & TV bảo vệ nghiêm ngặt khu DTSQ Cần Giờ & I. 1 & $3.212,18$ \\
\hline \multirow{5}{*}{$\begin{array}{l}\text { Vùng rừng } \\
\text { ngập mặn }\end{array}$} & & TV Vùng đệm khu DTSQ Cần Giờ & I. 2 & $16.219,26$ \\
\hline & & TV Chiến khu Rừng Sác & $\mathrm{I} .3$ & $2.077,87$ \\
\hline & & TV ruộng muối Thạnh An & $\mathrm{I} .4$ & $1.546,40$ \\
\hline & \multirow{8}{*}{ II } & TV cồn cát ven biển & II. 1 & 101,84 \\
\hline & & TV dân cư TT. Cần Thạnh & II. 2 & 728,18 \\
\hline \multirow{6}{*}{$\begin{array}{l}\text { Vùng đất } \\
\text { cát ven } \\
\text { biển }\end{array}$} & & TV Cây lâu năm Long Hòa & II. 3 & 483,73 \\
\hline & & TV dân cư Long Hòa & II. 4 & 187,09 \\
\hline & & TV Đất mặn ven sông & II.5 & 276,57 \\
\hline & & TV Lấn biển Cần Thạnh & II.7 & 75,16 \\
\hline & & TV rừng ngập mặn TT Cần Thạnh & II.6 & 849,65 \\
\hline & & TV Rừng ngập mặn Lý Nhơn & III.1 & 759,82 \\
\hline \multirow{6}{*}{$\begin{array}{l}\text { Vùng đất } \\
\text { cát ven } \\
\text { sông Soài } \\
\text { Rạp }\end{array}$} & \multirow{5}{*}{ III } & TV NTTS Lý Nhơn & III.2 & $2.245,14$ \\
\hline & & TV dân cư nông thôn Lý Nhơn & III. 3 & 481,36 \\
\hline & & $\begin{array}{l}\text { TV đất giồng cát phát triển trồng lúa và hoa } \\
\text { màu Lý Nhơn }\end{array}$ & III.4 & 307,51 \\
\hline & & TV đất mặn phát triển nghề làm muối Lý Nhơn & III.5 & $1.938,03$ \\
\hline & & TV rừng ngập mặn cửa sông Đồng Tranh & III.6 & $1.621,07$ \\
\hline & \multirow{6}{*}{ IV } & TV Đảo Thạnh An & IV.1 & 457,69 \\
\hline \multirow{5}{*}{$\begin{array}{l}\text { Vùng ngập } \\
\text { nước cửa } \\
\text { sông và } \\
\text { biển ven bờ }\end{array}$} & & TV bãi bồi ven biển & IV.2 & 545,26 \\
\hline & & TV bãi triều độ sâu $6 \mathrm{~m}$ & IV.3 & $9.243,51$ \\
\hline & & TV biển ven bờ độ sâu $>6 \mathrm{~m}$ & IV.4 & $14.653,64$ \\
\hline & & TV cửa sông Đồng Tranh & IV.5 & $2.985,91$ \\
\hline & & TV cửa sông Lòng Tàu & IV.6 & $2.698,22$ \\
\hline
\end{tabular}




\section{5. Đề xuất phân vùng chức năng vùng bò̀}

Sau khi xây dựng bản đồ phân vùng lãnh thổ vùng nghiên cứu, tiến hành phân tích các chức năng của các tiểu vùng.

Sử dụng công cụ phân tích SWOT như là một phương pháp nhằm đánh giá những điểm mạnh $(\mathrm{S})$, điểm yếu $(\mathrm{W})$, cơ hội $(\mathrm{O})$ và thách thức $(\mathrm{W})$ cho từng tiểu vùng lãnh thổ. Để có cơ sở xác định chức năng chính của từng tiểu vùng đề tài đã vận dụng phương pháp phân tích SWOT mở rộng như: Phát huy các điểm mạnh để nắm lấy các cơ hội $(\mathrm{S}-\mathrm{O})$; Phát huy các điểm mạnh để né tránh hoặc hạn chế các đe doạ $(\mathrm{S}-\mathrm{T})$; Khắc phục các điểm yếu để nắm lấy cơ hội $(\mathrm{W}-\mathrm{O})$; Khắc phục những điểm yếu để né tránh hoặc hạn chế các thách thức (W-T). Cùng với phương pháp chuyên gia, tham vấn cộng đồng, mô tả đặc điểm của từng tiểu vùng, phân tích SWOT là công cụ tổng hợp để xác định các chức năng cho từng tiểu vùng.

Trên cơ sở phân tích chức năng chính, chức năng phụ của các tiểu vùng, đồng thời tham khảo định hướng quy hoạch phát triển ở địa bàn nghiên cứu, các tiểu vùng chức năng được đề xuất như bảng 3 và hình 6 .
Không gian bảo vệ bảo tồn: bao gồm 05 tiểu vùng là I.1, I.2, I.3, II.1, III.1, bao gồm các tiểu vùng có chức năng bảo tồn hệ sinh thái, đa dạng sinh học, cảnh quan và hành lang bảo vệ bờ biển, tổng diện tích tự nhiên là 22.370,97ha chiếm $35,1 \%$ tổng diện tích vùng nghiên cứu.

Không gian phục hồi hệ sinh thái: là các tiểu vùng có chức năng phục hồi phát triển hệ sinh thái rừng ngập mặn, kết quả đánh giá và xác định được 3 tiểu vùng là I.1, I.2, I.3 với diện tích $4.017,12$ ha chiếm $6,30 \%$ diện tích lãnh thổ nghiên cứu.

Không gian sinh sống: là các tiểu vùng hiện trạng là vùng dân cư ở nông thôn, đồ thị hoặc đang được quy hoạch phát triển khu dân cư. Kết quả nghiên cứu đã xác định được 4 tiểu vùng là II.2, II.4, III.3, IV.1 với diện tích 1.854,32 ha chiếm 2,91\% tổng diện tích vùng nghiên cứu.

Không gian phát triển kinh tế - xã hội: đây là chức năng có số lượng tiểu vùng lớn nhất, diện tích lớn nhất, bao gồm các tiểu vùng có chức năng phát triển nông nghiệp, lâm nghiệp, NTTS, giao thông, cảng,... Trên địa bàn nghiên cứu đã xác định được 11 tiểu vùng với 35.425,68 ha chiếm 55,65\% diện tích lãnh thổ (Hình 6).

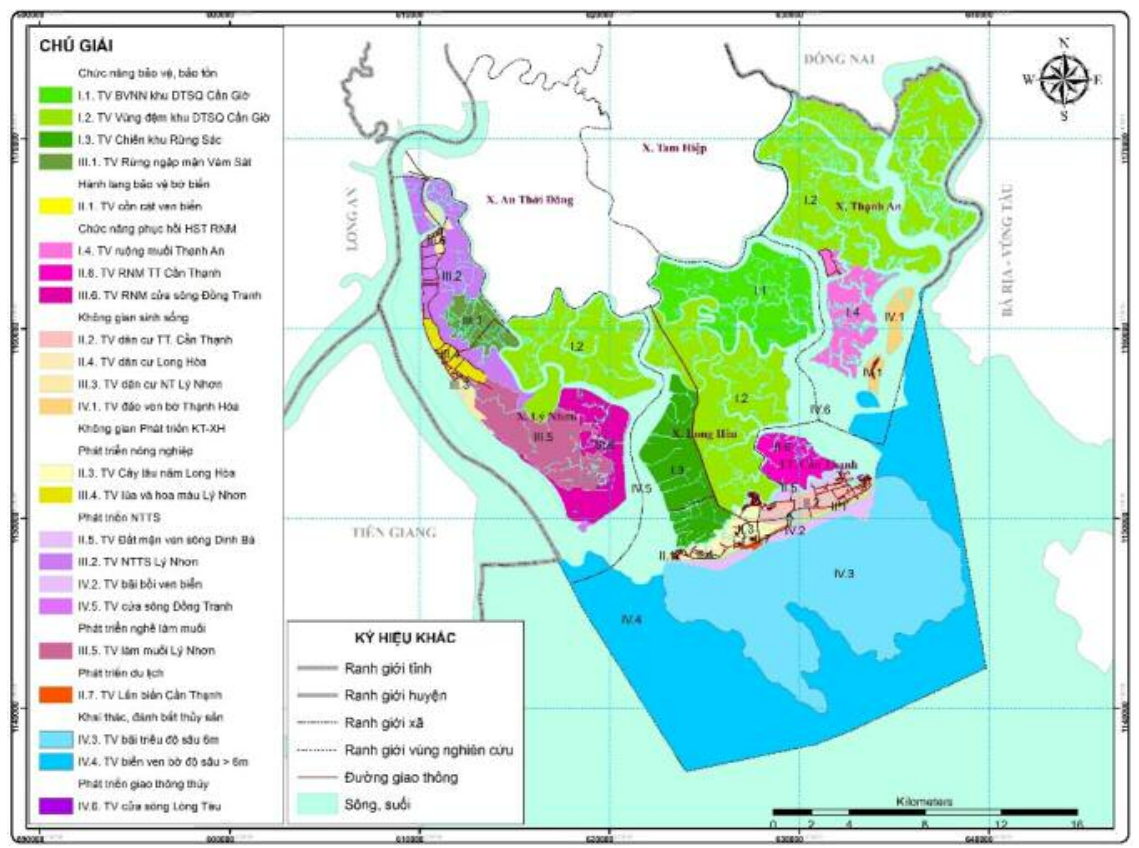

Hình 6. So đồ phân vùng chức năng vùng bò̀ Hồ Chí Minh 
Bảng 3. Đề xuất chức năng các tiểu vùng

\begin{tabular}{lcrl}
\hline \multicolumn{1}{c}{ Các chức năng } & Các tiểu vùng & Diện tích (ha) & Ghi chú \\
\hline Bảo vệ bảo tồn & I.1, I.2, I.3, II.1, III.1 & $22.370,97$ & \\
Phục hồi & I.4, II.6, III.6 & $4.017,12$ & \\
Không gian sống & II.2, II.4, III.3, IV.1 & $1.854,32$ & \\
$\begin{array}{l}\text { Phát triển kinh tế - xã } \\
\text { hội }\end{array}$ & II.3, II.5, II.7, III.2, & $35.452,68$ & $\begin{array}{l}\text { Bao gồm nhiều loại hình } \\
\text { như phát triể nông } \\
\text { nghiệp, NTTS, Đánh bắt } \\
\text { III. III.5, IV.2, IV.3, du lịch, giao thông ... }\end{array}$
\end{tabular}

\section{Kết luận}

Trên cơ sở đánh giá tổng hợp các yếu tố tự nhiên, môi trường theo các tiêu chí đã được xác định, nghiên cứu đã xác định trên lãnh thổ vùng bờ thành phố Hồ Chí Minh 4 vùng lãnh thổ có sự đồng nhất tương đối về điều kiện tự nhiên, tài nguyên thiên nhiên là: vùng đất cát ven sông Soài Rạp, vùng đất cát ven biển, vùng rừng ngập mặn và vùng ngập nước cửa sông-ven biển. Đây là đơn vị cơ sở để phân vùng chức năng vùng bờ cho mục tiêu phát triển bền vững và ứng phó với BĐKH.
Các bản đồ thành phần được chồng xếp như: địa chất, địa hình, thổ nhưỡng, thủy văn, thảm thực vật, môi trường, hiện trạng sử dụng tài nguyên, nghiên cứu đã phân chia lãnh thổ vùng bờ Hồ Chí Minh thành 4 vùng và 23 tiểu vùng đây là cơ sở để đề xuất các chức năng nhằm mục tiêu phát triển bền vững. Đồng thời nghiên cứu đề xuất chức năng vùng bờ Hồ Chí Minh theo 4 nhóm chính là: Chức năng bảo vệ bảo tồn (bao gồm hành lang bảo vệ bờ biển), chức năng phục hồi hệ sinh thái, chức năng không gian sinh sống và chức năng phát triển kinh tế - xã hội.

Lời cảm ơn: Nghiên cứu được tài trọ bởi Sở Khoa học và Công nghệ Tp. HCM trong khuôn khổ đề tài "Phân vùng chức năng vùng bờ thành phố Hồ Chí Minh".

\section{Tài liệu tham khảo}

1. Dũng, N.X. và cs (2012), Nghiên cúu, điều tra, đánh giá đa dạng sinh học khu dư trũ sinh quyển Cần Giờ, Hà Nội: Báo cáo tổng kết đề tài.

2. Lợi, Đ.V. và cs (2009), Nghiên cứu, xây dựng phương pháp luận phân vùng chức năng môi truờng phục vu công tác xây dưng quy họach, kế họach theo định hướng phát triển bền vĩng, Hà Nội: Báo cáo tổng kết đề tài, Bộ TNMT.

3. Nam, V.N. và cs (2008), Nghiên cứu đa dạng sinh học về thực vật trong phân khu bảo vệ nghiêm ngặt Khu Bảo tồn thiên nhiên rùng ngập mặn Cần Giờ, Hồ Chí Minh: Báo cáo tổng kết đề tài.

4. Phân viện QH\&TKNN (2000), Tài liệu khảo sát xây dụng bản đồ thổ nhương tỷ lệ 1/50.000, Hồ Chí Minh.

5. Thanh, L.N. và cs (2018), Nghiên cứu đánh giá tiềm năng tài nguyên thiên nhiên vùng ven biển Cần Giờ, thành phố Hồ Chí Minh và đề xuất các giải pháp bảo vệ thích hợp, Hồ Chí Minh: Báo cáo tổng kết đề tài.

6. UBND huyện Cần Giờ (2018). Báo cáo tình hình kinh tế - xã hội năm 2018, Hồ Chí Minh: UBND huyện Cần Giò. 


\title{
BÀI BÁO KHOA HỌC
}

\section{PROPOSING DISTRIBUTION OF COASTAL ZONE IN HO CHI MINH CITY}

\author{
Ngo Nam Thinh ${ }^{1}$, Nguyen Huy Anh', Nguyen Ky Phung ${ }^{2}$ \\ ${ }^{1}$ Ho Chi Minh University of Natural Resources and Environment \\ ${ }^{2}$ Department of Science and Technology, Ho Chi Minh City
}

\begin{abstract}
Distribution of coastal zone in Ho Chi Minh city which based on integrating of natural, environmental and economic conditions with supporting of GIS software was built. Results have divided the coastal zone into 4 regions, in which: 23 sub-zones and 04 main functions: protection and conservation with an area of 22.370,97 ha, accounting for 35\% of the total area; ecosystem restoration functions 4.017,12 (6\% of the total area); living environments 1.854,32 ha (3\% of the total area), finally, socio-economic development function covers 35.452,68 ha equivalence to 56\% of the planned area. The results of distributed zoning in Ho Chi Minh city coastal area is a scientific basis to build a suitable solution for socio-economic development and environmental protection in the future.
\end{abstract}

Keywords: Coastal areas, Can Gio district, distribution of coastal zone. 